\title{
Examining How Brand Co-Creation and Virtual Brand Community Affect Brand Commitment
}

\author{
Weijian $\mathrm{Lu}^{1, \mathrm{a}}$, Yu Han ${ }^{* 2, \mathrm{~b}}$, Shiyu Chen ${ }^{3, \mathrm{c}}$ \\ ${ }^{1}$ School of English for International Busienss Guangdong Univeristy of Foreign Studies Guangzhou, China \\ ${ }^{2}$ College of Professional Studies Northeastern University Boston, USA \\ ${ }^{3}$ College of Accounting Business College of Shanxi University Taiyuan, China
}

\begin{abstract}
The significance of brand co-creation in virtual brand communities has been recognized in academia and practice. The existing literature has investigated the impact of customer participation in virtual brand community on brand performance and its mechanism, but the prospective impact of types of virtual brand community on types of brand commitment is not examined. Based on the survey of 229 members in virtual brand communities of two popular games of Tencent, this research empirically examines how different types of brand co-creation and virtual brand communities influence brand commitment. This research confirms that customers participating in autonomous brand co-creation in the autonomous virtual brand community have a significantly higher degree of brand experience, and those who participate in both sponsored and autonomous virtual brand community have a comparatively lower degree of brand experience. Meanwhile, sub-brand brand commitment plays the role of mediator between brand experience and corporate brand commitment. Theoretical and managerial implications are offered with limitations and future research.
\end{abstract}

\section{Introduction}

In the past two decades, Service-Dominant Logic (S-D Logic) has developed rapidly, indicating that value is no longer solely created by the companies, but co-created by customers or other stakeholders [1]. Meanwhile, in view of the emergence of S-D Logic, companies are increasingly recognizing that brands are one of their most valuable assets, so they have invested more resources to build brands. Since the advent of the brand era and S-D Logic, as well as the era of Internet and virtual economy, scholars have discovered that the boundaries of value cocreation are extended and integrated into brand cocreation, which is recognized as a new paradigm of branding [2]. In this digital era, virtual brand communities have gradually become an essential platform for customers and companies to co-create the value [3]. In the communities, customers can participate in brandsponsored co-creation through hosted activities to create or improve products and promote community development by cooperating with the companies. Meanwhile, customers can participate in autonomous brand co-creation by sharing consumption experiences, product evaluation and knowledge, and interacting with other customers in the brand communities [4]. Regarding these topics, researchers have dived deep into brand cocreation and brand communities. By investigating three case studies of Starbucks, Apple, and Nike, researchers discovered how to implement brand co-creation through their participation platforms, especially online platforms, and explained the organizational practice of brand cocreation in the digital world [5]. Therefore, the theoretical and managerial values of brand co-creation and virtual communities have been recognized by researchers.

Since topics relating to brand co-creation and virtual brand communities have been investigated for more than a decade, the mechanism between brand co-creation and brand performance has been explored to some extent. Most of the researchers believe that customers who participate in brand co-creation will have outstanding experiences, which will further influence brand commitment. Although some researches are focused on the effects of types of brand experiences, most of the researchers still regard these experiences as a whole, which will lead to the absence of details of the mechanism [4]. Meanwhile, some of the researchers differentiate the types of co-creation, including brand- and-companysponsored co-creation and customer-autonomous brand co-creation. These will affect the brand experience and customer commitment, and further affect brand equity $[4,5]$. However, few researches have differentiated between types of virtual brand communities, which are also an essential variable in the effects of brand cocreation since they will affect customer participation and commitment. Meanwhile, brand commitment is recognized as a holistic concept without differentiation of sub-brand brand commitment and corporate brand commitment, which need to be investigated separately since they will lead to different results. In addition, few previous studies have discussed the topic of brand cocreation in virtual brand communities within the realm of 
virtual products. Most of the researchers chose subjects of physical products with virtual communities like mobile phones or shoes [5], offering incomprehensive advice towards companies in the developmental trends of the contemporary virtual economy.

A questionnaire survey was conducted in this research to investigate the virtual brand communities of the popular games under Tencent, which feature virtual consumption of products under virtual circumstances. Developing from previous studies, this work distinguishes the types of brand co-creation-autonomous brand co-creation and sponsored brand co-creation, and the types of virtual brand communities - autonomous virtual brand community and sponsored virtual brand community, and examines the relationships between their interaction and the brand experience. According to the literature, this work adopts a five-dimension brand experience model that contains sensory, affective, cognitive, behavioral, and relational experiences. At the same time, this work distinguishes the sub-brand brand commitment and the corporate brand commitment, and examines the relationship between them, as well as the relationship between the brand experience. The research questions are the followings. (1) In the sponsored and autonomous virtual brand communities, how do the sponsored and autonomous brand co-creations influence different dimensions of brand experience, and what are their differences? (2) Does brand experience influence sub-brand brand commitment and corporate brand commitment respectively? (3) Does sub-brand brand commitment work as a mediator between the brand experience and corporate brand commitment?

\section{Research Status and Hypotheses}

\subsection{Brand Co-creation and Virtual Brand Community}

The Virtual Brand Community is a virtual community where fans of specific brands congregate on the Internet. Many researchers have found that in the virtual brand community, users have more opportunities to interact with brands and other customers [6]. Not only do they work together in the production through their interaction with the company, but they can also create value in the customer domain by interacting with other customers, thus resulting in a typical platform for value co-creation [3]. Researchers have found out that the development of the Internet not only promotes the brand community but also stimulates the process of creating values. Therefore, the Internet offers more opportunities for interaction than offline methods. Payne et al. diagnosed and designed brand relationship experiences in the brand communities. They studied the concept of value co-creation and brand relationship experience in S-D logic and proposed a conceptual model for design and management of customer experience [7]. In the process of co-creation, the most important thing is the expansion of social media, which provides a broader and timely communication platform for brands and customers, thus promoting the development of online communities [8,9]. Virtual brand communities have been proven to be influential in the process of decision making of customers. In particular, sponsored virtual brand community has been recognized as an important platform for companies to convey their brand image [4]. Meanwhile, autonomous virtual brand community has become another important platform for customers to cocreate, even attract the brand to enter and interact with customers. This is especially common for the game industry since naturally it has the spirit of autonomy. When games are endowed with attributes of social communication and connection, virtual brand communities become an essential platform for players to interact actively and build emotional and behavioral identification with each other and with the brand or company [10]. Therefore, game virtual brand communities will be suitable for the exploration of research on sponsored and autonomous virtual brand communities.

From the perspective of brand co-creation, brand building is no longer the unilateral impact of companies on consumers, but consumers need to actively participate in the brand building with them. Since the line between producers and customers is blurring, and the development of the brand must be consumer-centric, customers become both the starting point and the endpoint of marketing [11]. The changes in the position of customers determine the change in brand strategy. Different from the previous passive acceptance of products and brands, customers nowadays want to participate in the production and require brands to produce what they want. They dislike the meaning imposed by the company on the brand, and they want to create the meaning of the brand according to their own wishes [9]. The previous studies explored the fivestage process model of brand co-creation [12]. Some researchers focused on conceptual models of relationship experience design and management. They believed that co-creation of brands between companies and customers is actually the process of brand relationship experiences based on interactive learning between the two parties [7]. In recent years, many Chinese scholars have started to investigate the systematic research on the impact of virtual brand community customer participation on brand performance and its mechanism [4,13]. Li, Jin, and $\mathrm{Bu}$ classified brand co-creation into sponsored and autonomous brand co-creation, which is adopted by most of the subsequent researchers, indicating that two types of brand co-creation will influence brand equity, loyalty, and commitment, etc. differently [14]. In these two types of brand co-creation, customers are in different positions and have different initiatives, which will lead to different results for brand performance [4].

\subsection{Brand Experience}

Brand experience is the subjective inner response and behavior performance of customers evoked by a series of stimuli related to the brand including products, brand design, and identification, packaging, communication, and environment [15]. Marketing practice and academia have raised many related concepts from different perspectives, such as customer, consumption, product, and service experiences, in accordance with the different links and 
different characteristics of experience in the consumption process [16-18]. Schmitt divides customer experience into five dimensions: sensory, affective, thinking, behavioral, and relational experiences [19]. Ramaswamy discovered that the participation of customers in the process of new product innovation can promote the formation of brand experience [2]. Zhu, Yuan, and Hao also found that brand co-creation will influence the five dimensions of brand experience [4]. The following hypotheses are proposed in this work based on the above research background:

H1: The interaction of participating in sponsored virtual brand communities and sponsored brand cocreation has a positive influence on brand experience.

$\mathrm{H} 1 \mathrm{a} / \mathrm{b} / \mathrm{c} / \mathrm{d} / \mathrm{e}$ : It has a positive influence on sensory/affective/thinking/behavioral/relational experience.

$\mathrm{H} 2$ : The interaction of participating in sponsored virtual brand communities and autonomous brand cocreation has a positive influence on brand experience.

$\mathrm{H} 2 \mathrm{a} / \mathrm{b} / \mathrm{c} / \mathrm{d} / \mathrm{e}$ : It has a positive influence on sensory/affective/thinking/behavioral/relational experience.

H3: The interaction of participating in autonomous virtual brand communities and sponsored brand cocreation has a positive influence on brand experience.

$\mathrm{H} 3 \mathrm{a} / \mathrm{b} / \mathrm{c} / \mathrm{d} / \mathrm{e}$ : It has a positive influence on sensory/affective/thinking/behavioral/relational experience.

H4: The interaction of participating in autonomous virtual brand communities and autonomous brand cocreation has a positive influence on brand experience.

$\mathrm{H} 4 \mathrm{a} / \mathrm{b} / \mathrm{c} / \mathrm{d} / \mathrm{e}$ : It has a positive influence on sensory/affective/thinking/behavioral/relational experience.

H5: The interaction of participating in both virtual brand communities and sponsored brand co-creation has a positive influence on brand experience.

$\mathrm{H} 5 \mathrm{a} / \mathrm{b} / \mathrm{c} / \mathrm{d} / \mathrm{e}$ : It has a positive influence on sensory/affective/thinking/behavioral/relational experience.

H6: The interaction of participating in both virtual brand communities and autonomous brand co-creation has a positive influence on brand experience.

$\mathrm{H} 6 \mathrm{a} / \mathrm{b} / \mathrm{c} / \mathrm{d} / \mathrm{e}$ : It has a positive influence on sensory/affective/thinking/behavioral/relational experience.

\subsection{Brand Commitment}

Brand commitment refers to the long-term desire and willingness of customers to establish a stable relationship with the brand [20]. Customers with high brand commitment have strong emotional attachment to the brand. They are willing to improve and maintain contact with the brand, so that they are satisfied. Researchers have explored the impact of community awareness on brand commitment in online brand communities. The researchers found that customers participated because they were interested in the brand or because of a certain relationship. After getting the experience, they have a sense of identity and belonging to the brand [21]. Studies have shown that consumers have a positive correlation between community and brand identity and brand commitment. The stronger the identity of the brand and the stronger the willingness to maintain it the brand are, the easier it is to form a brand commitment $[22,23]$. At the same time, other researchers also discussed the impact of value of online brand communities on brand commitment. The results show that community entertainment value can effectively improve the commitment and loyalty to the brand [24]. As for the impact of the characteristics of online brand community on brand commitment, the studies found that maximizing these characteristics can stimulate customer trust, and then promote the commitment of community members to the brand [25]. Research confirmed that brand experience positively affects brand personality, satisfaction, and loyalty [26]. Li, Jin, and $\mathrm{Bu}$ found that customer participation in virtual brand community influences the value co-creation and brand equity through the mediating role of brand experience [9]. Zhu, Deng, and Hao have confirmed that brand experience works as a mediator in the relationship between brand co-creation and brand commitment [4]. Meanwhile, the corporate brand and sub-brand should be individually discussed since researchers have proven that they would influence each other, and they would be influenced by other variables separately [27]. The following hypotheses are proposed in this work based on the above research background:

H7: Brand experience has a positive influence on corporate brand commitment.

H8: Brand experience has a positive influence on subbrand brand commitment.

H9: Sub-brand brand commitment works as a mediator between the brand experience and corporate brand commitment.

Based on the above analyses, the conceptual model of this study is proposed as shown in Figure 1:

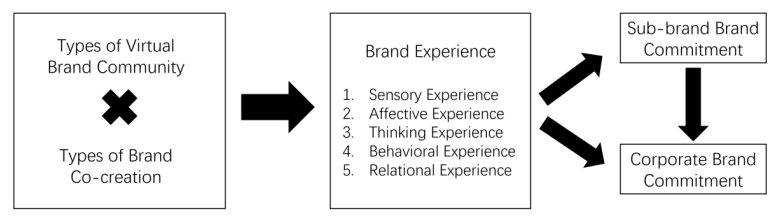

Fig1. Conceptual Model for This Work.

\section{Methodology}

This research is designed to reveal how different types of virtual communities and brand co-creation affect consumers' brand commitment through exploratory investigation. This study takes two typical games of the same type (Multiplayer Online Battle Arena) of Tencent as examples, Honor of Kings (mobile games) and League of Legends (PC games), in attempts to capture the players' opinions on how they establish the brand commitment to Tencent.

Although these measurement items are extracted from the previous authentic literature, this study conducted a preliminary study on 40 players of the two games to test the reliability and effectiveness of the measurement items. There are two main reasons for the researchers to modify 
and delete some items: 1) English translation items easy mislead Chinese respondents; 2) the reliability and validity of the items are not strong. EFA results retained a total of 10 factors with 33 measurement items.

\subsection{Data Collection}

This revised questionnaire was distributed online among more members who attended virtual communities of these two games (Honor of Kings and League of Legends), and then 229 responses were collected. Since the questionnaire requires respondents to complete all surveys, the collected results are all valid without missing values. The research sample demographics are shown in Table 1.

Table1. Research Sample Demographics

\begin{tabular}{|c|c|c|}
\hline $\begin{array}{c}\text { Demographic } \\
\text { Profile }\end{array}$ & $\begin{array}{c}\text { Number of } \\
\text { Respondents }\end{array}$ & Percentage \\
\hline \multicolumn{3}{|c|}{ Gender } \\
\hline Male & 136 & $59.39 \%$ \\
\hline Female & 93 & $40.61 \%$ \\
\hline \multicolumn{3}{|c|}{ Age } \\
\hline $0-17$ & 13 & $5.68 \%$ \\
\hline $18-25$ & 138 & $60.26 \%$ \\
\hline $26-30$ & 54 & $23.58 \%$ \\
\hline $30+$ & 24 & $10.48 \%$ \\
\hline \multicolumn{3}{|c|}{ Education } \\
\hline Primary School & 9 & $3.91 \%$ \\
\hline Middle School & 9 & $3.91 \%$ \\
\hline Professional School & 20 & $8.70 \%$ \\
\hline Undergraduate & 127 & $55.22 \%$ \\
\hline Postgraduate & 65 & $28.26 \%$ \\
\hline \multicolumn{3}{|c|}{ Virtual Brand Community Participation } \\
\hline Less than 1 year & 120 & $52.40 \%$ \\
\hline $1-3$ years & 42 & $18.34 \%$ \\
\hline $3-5$ years & 29 & $12.66 \%$ \\
\hline $5+$ years & 38 & $16.59 \%$ \\
\hline
\end{tabular}

It can be seen from the table that more males participate in virtual community discussions and brand cocreation. About eight of the total ten respondents hold undergraduate and postgraduate education degree, which is consistent with the results of the participants mainly concentrated in the age group 18-30. However, most of respondents have participated in the virtual community and brand co-creation for less than 1 year.

\subsection{Exploratory Factor Analysis}

Using principal component analysis as extraction method and varimax rotation as rotation method, 33 measurement items were analyzed with exploratory factor analysis (EFA). The breaks-in-Eigen criterion $(>1)$ was used to determine the number of factors to retain.

As these measurement items are borrowed from existing literature, their validity is good. The factor loadings of 33 measurement items are all around 0.85 , much greater than 0.5. Besides, SPSS is used to detect the Kaiser-Meyer-Olkin (KMO) of the questionnaire and the Bartlett's test is used to examine the fitness of the factor analysis of the questionnaire. Kaiser argued that the KMO value ranged from $0-1$. If the KMO value of the questionnaire is greater than 0.70 and the P-value is less than 0.05 , the factor analysis is appropriate. The three elements' KMOs are all greater than 0.85. Their Bartlett Sphericity tests are all significant at the level of 0.000 [28]. In this case, all measurement items are fit in factor analysis.

\subsection{Reliability and Validity Assessment}

"Construct validity refers to the degree of rationality of theoretical structure from the operational inference in the research to the basis of these operability" [29]. Confirmatory factor analysis (CFA) is an effective method to solve the problem of construct validity. Compared with Campbell and Fiske's criteria, CFA can reduce assumptions and provide more diagnostic information about reliability and validity [30]. CFA is conducted here to measure composite reliability, convergent validity and discriminant validity.

Reliability refers to the stability and consistency of the results measured by tests or measuring tools. Cronbach' $\alpha$ coefficients were calculated to evaluate the internal reliability of the measurement methods used in this study, ranging from 0 to 1 . It is generally considered that the value of coefficient should be greater than 0.70 [31]. In addition, all variables and scaled items shall show an over identified model, meet the CFA requirements, and be loaded on each structure over 0.5 . At this point, the cutoff value is set to 0.50 [32].

\subsubsection{Co-Creation}

Table2. Co-Creation CFA Results

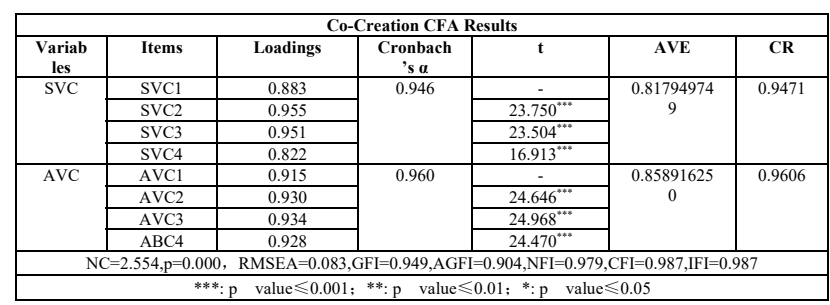

After removing one item that cannot fit the requirement of loading, the Co-creation retains a total of two variables with 8 measuring items as shown in TABLE 2. Their loadings are all around 0.9 , which is much higher than 0.5 . The average variance (AVE) of each factor and measurement item of the two reserved variables is at least 0.5 [33]. In this case, the convergent validity of the cocreation scale items can be confirmed.

\subsubsection{Brand Experience}

Table3. Brand Experience CFA Results

\begin{tabular}{|c|c|c|c|c|c|c|}
\hline \multicolumn{7}{|c|}{ Brand experience CFA Results } \\
\hline $\begin{array}{c}\text { Variabl } \\
\text { es }\end{array}$ & Items & $\begin{array}{c}\text { Loadin } \\
\text { gs }\end{array}$ & $\begin{array}{c}\text { Cronbac } \\
\text { h's } \alpha\end{array}$ & $\mathbf{t}$ & $\overline{\text { AVE }}$ & CR \\
\hline \multirow[t]{3}{*}{ SE } & SE1 & 0.873 & \multirow[t]{3}{*}{0.928} & - & \multirow{3}{*}{$\begin{array}{c}0.6401846 \\
67\end{array}$} & \multirow{3}{*}{$\begin{array}{c}0.842 \\
2\end{array}$} \\
\hline & SE2 & 0.924 & & $45.410^{* * * *}$ & & \\
\hline & SE3 & 0.907 & & $43.819^{* * * *}$ & & \\
\hline \multirow[t]{3}{*}{$\mathrm{AE}$} & $\mathrm{AE} 1$ & 0.879 & \multirow[t]{3}{*}{0.925} & - & \multirow[t]{3}{*}{0.569148} & \multirow{3}{*}{$\begin{array}{c}0.798 \\
3\end{array}$} \\
\hline & $\mathrm{AE} 2$ & 0.916 & & $42.61^{9^{* * *}}$ & & \\
\hline & $\mathrm{AE} 3$ & 0.901 & & $39.685^{* * *}$ & & \\
\hline \multirow[t]{3}{*}{$\mathrm{TE}$} & TE1 & 0.865 & \multirow[t]{3}{*}{0.919} & - & \multirow{3}{*}{$\begin{array}{c}0.5704426 \\
67\end{array}$} & \multirow{3}{*}{$\begin{array}{c}0.799 \\
1\end{array}$} \\
\hline & TE2 & 0.916 & & $42.625^{* * * *}$ & & \\
\hline & TE3 & 0.897 & & $42.415^{* * * *}$ & & \\
\hline \multirow[t]{3}{*}{$\mathrm{BE}$} & $\mathrm{BE} 1$ & 0.882 & \multirow[t]{3}{*}{0.935} & - & \multirow{3}{*}{$\begin{array}{c}0.6620616 \\
67\end{array}$} & \multirow{3}{*}{$\begin{array}{c}0.854 \\
6\end{array}$} \\
\hline & BE2 & 0.934 & & $43.923^{* * * *}$ & & \\
\hline & BE3 & 0.919 & & $43.726^{* * *}$ & & \\
\hline
\end{tabular}




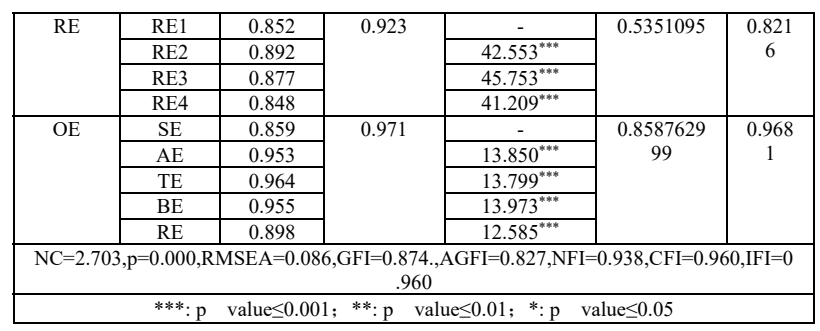

Table4. Discriminant Validity (AVE Results)

\begin{tabular}{|c|c|c|c|c|c|}
\hline \multicolumn{7}{|c|}{ Discriminant validity (AVE results) } \\
\hline Variables & SE & $\mathrm{AE}$ & $\mathrm{TE}$ & $\mathrm{BE}$ & $\mathrm{RE}$ \\
\hline $\mathrm{SE}$ & 0.800 & & & & \\
\hline $\mathrm{RE}$ & 0.898 & 0.754 & & & \\
\hline $\mathrm{BE}$ & 0.840 & 0.922 & 0.755 & & \\
\hline $\mathrm{TE}$ & 0.846 & 0.890 & 0.936 & 0.967 & \\
\hline $\mathrm{AE}$ & 0.757 & 0.815 & 0.825 & 0.841 & 0.732 \\
\hline
\end{tabular}

The convergent validity of the brand experience is confirmed as the loadings of measuring items are all around 0.9 , much more than 0.5 as shown in TABLE 3 . There is no need to remove any item. The average variance (AVE) of each factor and measurement item of two reserved variables is at least 0.5 as shown in TABLE 4 .

\subsubsection{Brand Commitment}

Table5. Brand Commitment CFA Results

\begin{tabular}{|c|c|c|c|c|c|c|}
\hline \multicolumn{7}{|c|}{ Brand Commitment CFA Results } \\
\hline $\begin{array}{c}\text { Variab } \\
\text { les }\end{array}$ & Items & $\begin{array}{c}\text { Loadin } \\
\text { gs }\end{array}$ & $\begin{array}{c}\text { Cronbac } \\
\text { h's } \alpha\end{array}$ & $\mathbf{t}$ & $\overline{\text { AVE }}$ & CR \\
\hline \multirow[t]{3}{*}{ SUB } & SUB1 & 0.820 & \multirow[t]{3}{*}{0.907} & - & \multirow[t]{3}{*}{0.795747} & \multirow{3}{*}{$\begin{array}{c}0.92 \\
09\end{array}$} \\
\hline & SUB2 & 0.955 & & $17.129^{* * * *}$ & & \\
\hline & SUB3 & 0.896 & & $16.431^{* * * *}$ & & \\
\hline \multirow[t]{3}{*}{ COR } & COR1 & 0.816 & \multirow[t]{3}{*}{0.918} & - & \multirow{3}{*}{$\begin{array}{c}0.754184 \\
333\end{array}$} & \multirow{3}{*}{$\begin{array}{c}0.90 \\
18\end{array}$} \\
\hline & COR2 & 0.891 & & $18.512^{* * * *}$ & & \\
\hline & COR3 & 0.896 & & $17.124^{* * * *}$ & & \\
\hline & & & $\begin{array}{c}\mathrm{FI}=0.986, A \\
.997\end{array}$ & $0.940, \mathrm{NF}$ & & \\
\hline
\end{tabular}

After removing two items that cannot fit the requirement of loading, the brand commitment retains a total of two variables with 8 measurement items as shown in TABLE 5. Their loadings are all around 0.8 , which is much higher than 0.5 . The average variance extracted (AVE) of each factor and measurement item of the two reserved variables is at least 0.5 [33]. In this case, the convergent validity of the brand commitment scale items can be confirmed.

\subsection{Hypothesis Test}

\subsubsection{H1-H6 Test}

Table6. Regression Analysis Results

\begin{tabular}{|c|c|c|c|c|}
\hline \multicolumn{5}{|c|}{ Regression Analysis Results } \\
\hline Hypothesis Paths & $\begin{array}{c}\text { Standardized } \\
\text { Estimation }\end{array}$ & C.R. & Sig. & Hypothesis \\
\hline H1a: $\mathrm{SBC}^{*} \mathrm{SVC} \rightarrow \mathrm{SE}$ & 0.548 & 6.491 & 0.000 & Valid \\
\hline H1b: SBC*SVC $\rightarrow \mathrm{AE}$ & 0.702 & 9.756 & 0.000 & Valid \\
\hline H1c: $\mathrm{SBC}^{*} \mathrm{SVC} \rightarrow \mathrm{TE}$ & 0.689 & 9.419 & 0.000 & Valid \\
\hline H1d: $\mathrm{SBC}^{*} \mathrm{SVC} \rightarrow \mathrm{BE}$ & 0.601 & 7.445 & 0.000 & Valid \\
\hline H1e: $\mathrm{SBC}^{*} \mathrm{SVC} \rightarrow \mathrm{RE}$ & 0.611 & 7.633 & 0.000 & Valid \\
\hline H2a $: \mathrm{SBC}^{*} \mathrm{AVC} \rightarrow \mathrm{SE}$ & 0.540 & 6.347 & 0.000 & Valid \\
\hline H2b: $\mathrm{SBC}^{*} \mathrm{AVC} \rightarrow \mathrm{AE}$ & 0.691 & 9.456 & 0.000 & Valid \\
\hline H2c: $\mathrm{SBC}^{*} \mathrm{AVC} \rightarrow \mathrm{TE}$ & 0.722 & 10.341 & 0.000 & Valid \\
\hline H2d: SBC*AVC $\rightarrow \mathrm{BE}$ & 0.61 & 7.617 & 0.000 & Valid \\
\hline H2e: $\mathrm{SBC}^{*} \mathrm{AVC} \rightarrow \mathrm{RE}$ & 0.592 & 7.269 & 0.000 & Valid \\
\hline H3a: $\mathrm{ABC} * \mathrm{SVC} \rightarrow \mathrm{SE}$ & 0.652 & 6.486 & 0.000 & Valid \\
\hline
\end{tabular}

\begin{tabular}{|c|c|c|c|c|}
\hline $\mathrm{H} 3 \mathrm{~b}: \mathrm{ABC} * \mathrm{SVC} \rightarrow \mathrm{AE}$ & 0.736 & 8.214 & 0.000 & Valid \\
\hline $\mathrm{H} 3 \mathrm{c}: \mathrm{ABC} * \mathrm{SVC} \rightarrow \mathrm{TE}$ & 0.629 & 6.105 & 0.000 & Valid \\
\hline H3d: ABC*SVC $\rightarrow$ BE & 0.668 & 6.785 & 0.000 & Valid \\
\hline H3e: $\mathrm{ABC} * \mathrm{SVC} \rightarrow \mathrm{RE}$ & 0.655 & 6.551 & 0.000 & Valid \\
\hline H4a: ABC*AVC $\rightarrow$ SE & 0.691 & 7.220 & 0.000 & Valid \\
\hline $\mathrm{H} 4 \mathrm{~b}: \mathrm{ABC} * \mathrm{AVC} \rightarrow \mathrm{AE}$ & 0.804 & 10.223 & 0.000 & Valid \\
\hline $\mathrm{H} 4 \mathrm{c}: \mathrm{ABC} * \mathrm{AVC} \rightarrow \mathrm{TE}$ & 0.729 & 8.030 & 0.000 & Valid \\
\hline H4d: $\mathrm{ABC} * \mathrm{AVC} \rightarrow \mathrm{BE}$ & 0.734 & 8.171 & 0.000 & Valid \\
\hline $\mathrm{H} 4 \mathrm{e}: \mathrm{ABC} * \mathrm{AVC} \rightarrow \mathrm{RE}$ & 0.718 & 7.784 & 0.000 & Valid \\
\hline H5a: BBC*SVC $\rightarrow$ SE & 0.534 & 5.208 & 0.000 & Valid \\
\hline $\mathrm{H} 5 \mathrm{~b}: \mathrm{BBC} * \mathrm{SVC} \rightarrow \mathrm{AE}$ & 0.575 & 5.795 & 0.000 & Valid \\
\hline $\mathrm{H} 5 \mathrm{c}: \mathrm{BBC} * \mathrm{SVC} \rightarrow \mathrm{TE}$ & 0.524 & 5.078 & 0.000 & Valid \\
\hline H5d: $\mathrm{BBC} * \mathrm{SVC} \rightarrow \mathrm{BE}$ & 0.555 & 5.497 & 0.000 & Valid \\
\hline H5e: $\mathrm{BBC} * \mathrm{SVC} \rightarrow \mathrm{RE}$ & 0.438 & 4.019 & 0.000 & Valid \\
\hline H6a: BBC*AVC $\rightarrow$ SE & 0.456 & 4.229 & 0.000 & Valid \\
\hline H6b: $\mathrm{BBC}^{*} \mathrm{AVC} \rightarrow \mathrm{AE}$ & 0.595 & 6.109 & 0.000 & Valid \\
\hline H6c: $\mathrm{BBC}^{*} \mathrm{AVC} \rightarrow \mathrm{TE}$ & 0.635 & 6.771 & 0.000 & Valid \\
\hline H6d: BBC*AVC $\rightarrow$ BE & 0.633 & 6.739 & 0.000 & Valid \\
\hline H6e: $\mathrm{BBC}^{*} \mathrm{AVC} \rightarrow \mathrm{RE}$ & 0.709 & 8.300 & 0.000 & Valid \\
\hline
\end{tabular}

This study conducts regression analysis through SPSS as shown in TABLE 6. The hypothesis 1a attempts to conclude that the SBC and SVC positively affect SE. In order to examine that, researchers input SBC mean and SVC mean as independent variables, and input the SE mean as a dependent variable. The calculated results show SBC and SVC have a significant influence on SE, and the H1a is valid $(\beta=0.548$, T value $=6.491, \mathrm{P}$ value $<0.001)$. Next, the same procedure was repeated for 29 times. The results indicate that $\mathrm{H} 1-\mathrm{H} 6$ are all valid.

\subsubsection{H7-H9 Test}

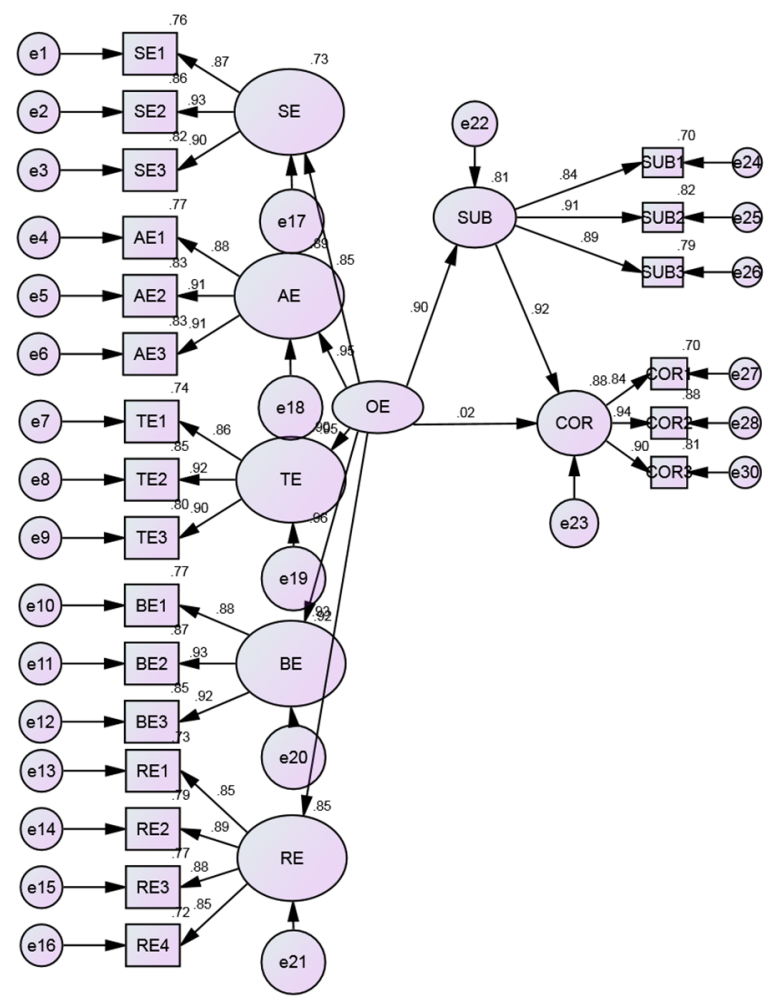

\begin{tabular}{|c|c|c|c|c|c|c|c|c|c|c|}
\hline & $\mathrm{X}^{2}$ & df & $\begin{array}{c}\mathrm{X} 2 / \\
\mathrm{df}\end{array}$ & $\begin{array}{c}\text { GF } \\
\text { I }\end{array}$ & $\begin{array}{c}\text { AG } \\
\text { FI }\end{array}$ & $\begin{array}{c}\text { NF } \\
\text { I }\end{array}$ & IFI & $\begin{array}{c}\text { TL } \\
\text { I }\end{array}$ & $\begin{array}{c}\text { CF } \\
\text { I }\end{array}$ & $\begin{array}{c}\text { RMS } \\
\text { EA }\end{array}$ \\
\hline $\begin{array}{c}\text { Recommende } \\
\text { d Values }\end{array}$ & & & $<3$ & $\begin{array}{l}>0 . \\
9\end{array}$ & $\begin{array}{l}>0 . \\
9\end{array}$ & $\begin{array}{l}>0 . \\
9\end{array}$ & $\begin{array}{l}>0 . \\
9\end{array}$ & $\begin{array}{l}>0 . \\
9\end{array}$ & $\begin{array}{l}>0 . \\
9\end{array}$ & $<0.08$ \\
\hline \begin{tabular}{|l|} 
Fit Index \\
\end{tabular} & $\begin{array}{l}554 . \\
300\end{array}$ & $\begin{array}{l}2 \\
0 \\
1\end{array}$ & $\begin{array}{l}2.7 \\
58\end{array}$ & $\begin{array}{l}0.8 \\
17\end{array}$ & $\begin{array}{l}0.7 \\
70\end{array}$ & $\begin{array}{l}0.9 \\
11\end{array}$ & $\begin{array}{l}0.9 \\
41\end{array}$ & $\begin{array}{l}0.9 \\
32\end{array}$ & $\begin{array}{l}0.9 \\
41\end{array}$ & 0.088 \\
\hline
\end{tabular}

Fig2. SEM of SUB, COR and OE

In order to examine the relationship among COR, SUB, and OE, this study uses AMOS to do a Structural 
Equations Modeling (SEM) as shown in Figure 2. The chisquare/df 2.758, p-value 0.000 , goodness of fit index (GIF) 0.817, comparative fit index (CFI) 0.941, RMSEA 0.088, normed fit index (NFI) 0.911, and incremental fit index (IFI) 0.941 , sufficiently indicate that the hypotheses of the model are quite consistent with the sample [32]. Therefore, it indicates that $\mathrm{H} 7, \mathrm{H} 8, \mathrm{H} 9$ are valid.

\section{Results and Discussion}

This study adopts two popular games of Tencent's, Honor of Kings and League of Legends as samples to verify that participating in virtual community and brand co-creation has a significant positive impact on user experience. The good user experience could indirectly improve the users' commitment to the corporation through the mediation role of sub-brand brand commitment.

From $\mathrm{H} 1$ to H5, the standard estimation of AE and TE are higher than SE, BE, and RE. It shows that when customers are participating in brand co-creation and virtual brand community, the customers' affective experience and thinking experience are easily improved. In all hypothesis verification, the standard estimation of $\mathrm{SE}$ is always lower than BE, AE, TE, RE's, which shows that regardless of the type of brand co-creation and virtual brand community, the customers' sensory experience is the most difficult to be improved. The overall standard estimation of the pair of $\mathrm{H} 3$ and $\mathrm{H} 4$ isThe research questions are higher than that of $\mathrm{H} 1$ and $\mathrm{H} 2$, indicating that the autonomous virtual brand community is easier to improve the user experience than the sponsored virtual brand community. In addition, $\mathrm{ABC} * \mathrm{AVC}$ has a higher standard estimation for $\mathrm{OE}$ than $\mathrm{ABC} * \mathrm{SVC}$. It means that participating in both autonomous virtual brand community and autonomous brand co-creation is easier to improve the user experience than participating in both autonomous virtual brand community and sponsored brand co-creation. Comparing with $\mathrm{H} 1-\mathrm{H} 4$, the standard estimations of $\mathrm{H} 8$ and $\mathrm{H} 9$ are lower, which means participating in two communities at the same time will not promote the user experience, but to a certain extent will reduce the overall experience. Comparing $\mathrm{H} 5$ and $\mathrm{H} 6$, the overall standard estimation of $\mathrm{H} 6$ is higher than that of H5. This demonstrates that when participating in both communities, customers who are participating in autonomous brand cocreation still have better experience than sponsored brand co-creation. The standard estimation of $\mathrm{BBC} * \mathrm{AVC}$ to RE is much greater than that of $\mathrm{BBC} * \mathrm{SVC}$ indicating that the autonomous brand co-creation can improve the relational experience. Moreover, the autonomous brand co-creation and autonomous virtual brand community can better improve the customers' relational experience. From $\mathrm{H} 1$ to H6, the overall standard estimation of $\mathrm{H} 4$ is the greatest. This means that the customers who are participating in the autonomous virtual brand community and autonomous brand co-creation could have the best experience. In contrast, the overall standard estimation of $\mathrm{H} 5$ is the lowest. This means that the customers who are participating in virtual brand communities and co-creation could slightly influence the experience.

The standard estimation of OE to SUB is 0.9, indicating that the brand experience directly affects the customers' brand commitment to the sub-brand. In other words, because of the improvement of the experience, people would have an emotional favor for the service, and produce a continuous behavior. Similarly, the standard estimation of SUB to COR is 0.92, which shows that the sub-brand brand commitment directly affects the customers' corporate brand commitment, leading the customers to become loyal to the entire corporation. The standard estimation of OE to COR is only 0.02 , indicating that there is almost no direct relationship between user experience and corporate brand commitment. In this case, sub-brand brand commitment plays the role of mediator between brand experience and corporate brand commitment.

The theoretical implications lie in it. first of all, this study expands the previous conceptual framework and adds new variables of virtual brand community type and brand commitment type. By introducing these variables, this study clarifies the interactive effect of the collaborative creation of the virtual brand community and brand. It shows that with the development of virtual economy, new variables in the virtual brand community will be found and worth studying because new technology and different national conditions will create unique individual and group behavior forms in online, offline, or even AR and VR settings. At the same time, with the extension of the sub-brand in the company, the impact on the sub-brand and corporate brand should be investigated separately. Through this study, the sub-brand brand commitment and corporate brand commitment are proved to be in the relationship of mediation. This will remind future researchers that if the above two variables are not considered to be different, the directionality of the behavioral and emotional bond between customers and brands or sub-brands will be inaccurate. Secondly, this study expands the research topics of brand co-creation and virtual brand community, focusing on the "purely virtual" setting, which means that customers purchase virtual products in virtual games, co-create with brands and other customers in the virtual brand community, and there is no physical connection or contact at any stage of consumption or co-creation. In the past, most of the researches chose customers of the brands with physical products as research subjects. With the development of AR and VR technology, the importance and malleability of the virtual economy will be further recognized and emphasized. Therefore, the setting of this study is worthy of being studied and adopted by other scholars. Thirdly, the scale of this study has been successfully developed, with high reliability and validity. It has been greatly improved compared with the previous literature, which is more suitable for the Chinese environment and virtual environment. Fourthly, the mediating effect of sub-brand brand commitment shows that through the development of sub-brand brand commitment, corporate brand commitment increases. This proves the inference that there are different effects between sub-brand brand commitment and corporate brand commitment.

The managerial implications lie in: first of all, the results of this study are particularly useful for the brand with virtual products, such as game brand. The 
autonomous virtual brand community is a better place for customers to participate in the co-creation of the brand. The autonomous brand co-creation in the autonomous virtual brand community has the most influence in all brand co-creation activities. Therefore, companies should focus on stimulating customers to co-create brand in an autonomous way in autonomous virtual brand communities. At the same time, participation in both sponsored and autonomous virtual brand communities will negatively influence the brand experience of customers, but the relational experience will be higher if autonomous brand co-creation is conducted. Therefore, autonomous brand co-creation is the most influential variable, and enterprises should pay attention to this it in any case. Secondly, the mediating role of sub-brand brand commitment implies that companies must pay attention to the development of sub-brand loyalty and sub-brand performance because these will eventually increase corporate brand commitment. At the same time, experiential marketing is very important for virtual products, but due to the lack of offline interaction with employees, experiential marketing for virtual products is different from traditional experiential marketing. Therefore, the virtual brand community provides a valuable channel for customers to interact with the brands. For companies, in order to increase their corporate brand commitment, it is necessary to increase customers' participation and enthusiasm in the sub-brand community. It is clear that brand experience is essential in the whole process of virtual consumption. Through the research of this work, emotional experience and thinking experience will be greatly affected in most cases, so companies and brands need to pay attention to these two experiences.

\section{Conclusion}

Inquiring into the literature, this study has found out that previous studies have not focused on the interaction effects of types of brand co-creation and virtual brand community. Meanwhile, sub-brand brand commitment and corporate brand commitment are not separately discussed. Based on the analysis of literature of virtual brand community and brand co-creation, this study has investigated the effects of these two variables on brand experience, and further influence sub-brand and corporate brand commitment. This work demonstrates that customers who participate in autonomous brand cocreation in the autonomous virtual brand communities have a higher brand experience, while customers who participate in both sponsored and autonomous virtual brand communities have a relatively lower brand experience. At the same time, sub-brand brand commitment plays a mediating role between the brand experience and the corporate brand commitment. Future research can be focused on the following directions. Firstly, future research could be further focused on the demographic variables so that it can improve managerial contributions to the practitioners. Secondly, future research could extend the subject and setting of other industries and other countries, so the validity of the model can be further improved. Moreover, future researches could try to investigate the differences between brands with physical products and virtual products, even extending to brands with virtual service and offline service. Lastly, future researchers could investigate the different effects of prospective types of virtual brand community, such as third-party-hosted brand community. In addition, researchers could investigate creativity and innovation in the process of brand co-creation in virtual brand communities, which would be full of theoretical and managerial contributions.

\section{References}

1. Vargo, S., Lusch, R., Akaka, M., \& He, Y. (2010). Service-Dominant Logic: A Review and Assessment. Review of Marketing Research, 6, 125-167.

2. Ramaswamy, V. (2009). Co-creation of value towards an expanded paradigm of value creation. Marketing Review St. Gallen, 26(6), 11-17.

3. Schau, H. J., Muñiz, A. M., \& Arnould, E. J. (2009). How Brand Community Practices Create Value. Journal of Marketing, 73(5), 30-51.

4. Zhu, L., Yuan, D., \& Hao, J. (2018). Research on the Effect of Customer Engagement in Brand CoCreation on Brand Commitment in Virtual Brand Community_-The Mediating Effects of Brand Experience. Chinese Journal of Management, 15(2), 262-271.

5. Ramaswamy, V., \& Ozcan, K. (2016). Brand value cocreation in a digitalized world: An integrative framework and research implications. International Journal of Research in Marketing, 33(1), 93-106.

6. Algesheimer, R., Dholakia, U. M., \& Herrmann, A. (2005). The Social Influence of Brand Community: Evidence from European Car Clubs. Journal of Marketing, 69(3), 19-34.

7. Payne, A., Storbacka, K., Frow, P., \& Knox, S. (2009). Co-creating brands: Diagnosing and designing the relationship experience. Journal of Business Research, 62(3), 379-389.

8. Dessart, L., Veloutsou, C., \& Morgan-Thomas, A. (2015). Consumer engagement in online brand communities: a social media perspective. Journal of Product \& Brand Management, 24(1), 28-42.

9. Essamri, A., McKechnie, S., \& Winklhofer, H. (2019). Co-creating corporate brand identity with online brand communities: A managerial perspective. Journal of Business Research, 96, 366-375.

10. Lortie, C. L., \& Guitton, M. J. (2012). Looking Similar Promotes Group Stability in a Game-Based Virtual Community. Games for Health Journal, 1(4), 274.

11. Kim, Y., \& Slotegraaf, R. J. (2016). Brand-embedded interaction: a dynamic and personalized interaction for co-creation. Marketing Letters, 27(1), 183-193.

12. Boyle, E. (2007). A process model of brand cocreation: brand management and research implications. Journal of Product \& Brand Management, 16(2), 122-131. 
13. Xue, Z., \& Ning, C. H. (2017). The Effect of Brand Co-creation on Brand Identification: From the Perspective of Non-Participants. East China Economic Management, 9, 154-162.

14. Li, Z., Jin, Y., \& Bu, Q. (2014). Research on the Effect of Customer Participation in Value Co-Creation on Brand Equity in Virtual Brand Community_-The Mediating Effects of Brand Experience. Journal of Marketing Science, 10(4), 109-124.

15. Brakus, J. J., Schmitt, B. H., \& Zarantonello, L. (2009). Brand Experience: What is It? How is it Measured? Does it Affect Loyalty? Journal of Marketing, 73(3), 52-68.

16. Meyer, C., \& Schwager, A. (2007). Understanding Customer Experience. Harvard Business Review, 85(2), 116-126, 157.

17. Hoch, S. (2002). Product Experience Is Seductive. Journal of Consumer Research, 29, 448-454.

18. Holbrook, M. B., \& Hirschman, E. C. (1982). The Experiential Aspects of Consumption: Consumer Fantasies, Feelings, and Fun. Journal of Consumer Research, 9(2), 132-140.

19. Schmitt, B. H. (1999). Experiential Marketing: How to get Customers to Sense, Feel, Think, Act and Relate to your Company and Brands. New York: Free Press.

20. Fournier, S. (1998). Consumers and Their Brands: Developing Relationship Theory in Consumer Research. Journal of Consumer Research, 24(4), 343373.

21. Traylor, M. B. (1981). Product Involvement and Brand Commitment. Journal of Advertising Research, 21(6), 51-56.

22. Warrington, P., \& Shim, S. (2000). An empirical investigation of the relationship between product involvement and brand commitment. Psychology \& Marketing, 17(9), 761-782.

23. Robin A, C., Linda L, P., \& Lawrence, F. (2003). Rethinking the Origins of Involvement and Brand Commitment: Insights from Postsocialist Central Europe. Journal of Consumer Research, 30(2), p.151169.

24. Chaudhuri, A., \& Holbrook, M. B. (2002). Productclass effects on brand commitment and brand outcomes: The role of brand trust and brand affect. Journal of Brand Management, 10(1), 33-58.

25. Turri, A. M., Smith, K. H., \& Kemp, E. (2013). Developing Affective Brand Commitment through Social Media. Journal of Electronic Commerce Research, 14(3), 201-214.

26. Das, G., Agarwal, J., Malhotra, N. K., \& Varshneya, G. (2018). Does brand experience translate into brand commitment?: A mediated-moderation model of brand passion and perceived brand ethicality. Journal of Business Research, 95, 479-490.

27. Wang, Y.-C., Qu, H., \& Yang, J. (2019). The formation of sub-brand love and corporate brand love in hotel brand portfolios. International Journal of
Hospitality Management, 77, 375-384.

28. Kaiser, H. F. (1974). An index of factorial simplicity. Psychometrika, 39, 31-36.

29. Trochim, W.M. \& Donnelly, J.P. (2008) Research methods knowledge base, Atomic Dog/Cengage Learning Mason, $\mathrm{OH}$.

30. Bagozzi, R. P., Yi, Y., \& Phillips, L. W. (1991). Assessing Construct Validity in Organizational Research. Administrative Science Quarterly, 36(3), 421-458.

31. Cronbach, L. J. (1951). Coefficient Alpha and Internal Structure of Tests. Psychometrika, 16(3), 297-334.

32. Kline, R. B. (2005). Principles and Practice of Structural Equation Modeling (2nd ed.). New York: Guilford

33. Fornell, C., and Larcker, D. F. (1981). Evaluating Structural Equation Models with Unobservable Variables and Measurement Error. Journal of Marketing Research, 18(1), 39-50. 